\title{
Phytoplankton responses to nutrient status: application of a screening method to the northern Baltic Sea
}

\author{
Jacob Carstensen ${ }^{1,2, *}$, Anna-Stiina Heiskanen ${ }^{1}$ \\ ${ }^{1}$ European Commission - Joint Research Centre, Institute for Environment and Sustainability, TP 290, Via E. Fermi 1, \\ 21020 Ispra, Italy \\ ${ }^{2}$ Department of Marine Ecology, National Environmental Research Institute, Frederiksborgvej 399, 4000 Roskilde, Denmark
}

\begin{abstract}
Phytoplankton monitoring data from the coastal northern Baltic Sea were analyzed in order to investigate whether changes in species composition could be related to nutrient levels. In this study 76 phytoplankton taxonomic units, identified to either species or genus level, that were present in at least $5 \%$ of all samples $(\mathrm{N}=2217)$, were examined for the Gulf of Riga, the Gulf of Finland and the Archipelago Sea. The presence of a particular species/genera was modeled by means of response surfaces describing the probability of that species/genus being present in a sample as a function of salinity and total nitrogen (TN), total phosphorus (TP) or N:P ratio. The probability of presence was significantly related to nutrient levels for only half of the phytoplankton units; 4 species/genera had probabilities ranging over $30 \%$ for changing nutrient levels; only 1 species (Planktothrix agardhii) allowed the detection of a change in the probability of presence from realistic sample sizes $(\mathrm{N}=50)$ when TN was decreased by $20 \%$, and only for a limited range of salinity and TN levels. Significantly, responses to changing nutrient levels were not specific to any of the different taxonomical divisions. Our results confirm that phytoplankton composition changes with different nutrient levels but that the composition does not shift abruptedly and changes are small for moderate increases in nutrient levels. The method developed enables screening of phytoplankton taxa that occur in response to elevated nutrient status, providing a tool for the selection of potential indicator species. This could prove useful in the further development of classification systems for coastal waters.
\end{abstract}

KEY WORDS: Eutrophication · Nitrogen · Phosphorus · Indicator species · Response surfaces · Power analysis $\cdot$ Planktothrix agardhii

Resale or republication not permitted without written consent of the publisher

\section{INTRODUCTION}

Nutrient enrichment of coastal waters has generally led to increases in phytoplankton biomass and primary production, although physical and biological features of the ecosystem may modulate the response (Cloern 2001, Yunev et al. 2005). Changes in phytoplankton composition have often been linked with increasing nutrient inputs and particularly to altered nutrient ratios (Cloern 2001). The most recognized example is probably the decrease in the $\mathrm{Si}: \mathrm{N}$ ratio stemming from increased nitrogen delivery to coastal water, in some cases combined with Si retention from dam construction (e.g. Humborg et al. 2000); this can precipitate changes from diatoms to species with smaller $\mathrm{Si}$ requirements (Conley et al. 1993). Case studies illustrating community responses to changes in $\mathrm{Si}: \mathrm{N}$ ratio include the offshore waters of the northern Gulf of Mexico (Rabalais et al. 1996), the Black Sea (Humborg et al. 1997), and the coastal Baltic Sea (Kuosa et al. 1997). Changes in the N:P ratio below the Redfield ratio of 16 are also considered to favor the growth of the nitrogen-fixing toxic cyanobacteria in the Baltic Sea (Niemi 1979) as well as the nuisance flagellate 
Phaeocystis sp. in waters with low Si concentrations, such as the North Sea (Egge \& Aksnes 1992, Lancelot 1995).

In some cases, changes in phytoplankton composition may occur as a regime shift from one community type to another (Philippart et al. 2000). Egge \& Aksnes (1992) suggested diatoms are outcompeted by flagellates if $\mathrm{Si}$ concentrations fall below a threshold of ca. $2 \mu \mathrm{M}$. In recent studies, not only the element ratio but also the composition of available inorganic nitrogen has been suggested as an important structuring factor (Tungaraza et al. 2003), as well as the organic nitrogen composition (Anderson et al. 2002).

The phytoplankton community response to nutrient conditions has mainly been studied by means of mesocosm experiments, with the addition of nutrients in different doses and ratios (Escaravage et al. 1996, Olli et al. 1996, Schollhorn \& Graneli 1996, Escaravage et al. 1999, Gonzales 2000). Most phytoplankton taxa generally respond positively to nutrient enrichment, with the exception of picoplankton; however, the fate of the increased production varies between different types of ecosystems (Olsen et al. 2001). By comparison with the science of limnology, whole-lake enrichment experiments have similarly shown changes in phytoplankton composition (Schindler 1987). Cottingham \& Carpenter (1998) suggested that indicators at the ecosystem level (biomass and productivity) and community level (genera, taxonomic division, allometric variates and community diversity) were more reliable indicators of enrichment than specific populations of single species because most taxa were not sufficiently present during a single year to reliably analyze for changes. The increasing occurrence of harmful algal blooms is also suggested to be linked to nutrient enrichment, although this has not been rigorously proven (Haellegraff 1993, Cloern 2001).

Nutrient enrichment is, however, not the only structuring mechanism for phytoplankton composition that has to be addressed in coastal waters. Light, turbidity, turbulence, stratification, salinity and the availability of micronutrients, as well as benthic and pelagic grazing, all add to the complex mosaic of structuring mechanisms for phytoplankton composition. Some of these mechanisms act on a species level, whereas other mechanisms act on a taxonomic or functional group level (Pinckney et al. 1999). Stratified waters have a relatively higher abundance of motile species (e.g. dinoflagellates) whereas mixed conditions typically favor diatoms (Sellner et al. 2001). This implies that phytoplankton composition may be specific for different habitats with specific salinity and hydrodynamic conditions.

The link between community structure and nutrient conditions suggests that phytoplankton composition may provide indicators for assessing the ecological quality of coastal waters. In fact, it is specifically formulated within the European Water Framework Directive (European Union 2000) that the ecological status of coastal water bodies should be assessed by means of biological quality elements, including parameters such as the taxonomic composition of phytoplankton (e.g. Heiskanen et al. 2004). However, it should be acknowledged that phytoplankton data are associated with considerable variation, allowing only for relatively large changes to be detected without excessive data, and therefore any phytoplankton species indicative of increased trophic status should have a significant response to relatively small changes in the nutrient conditions (Fig. 1A). This implies that such taxa or species-specific parameters are only valid for assessing ecological quality within a
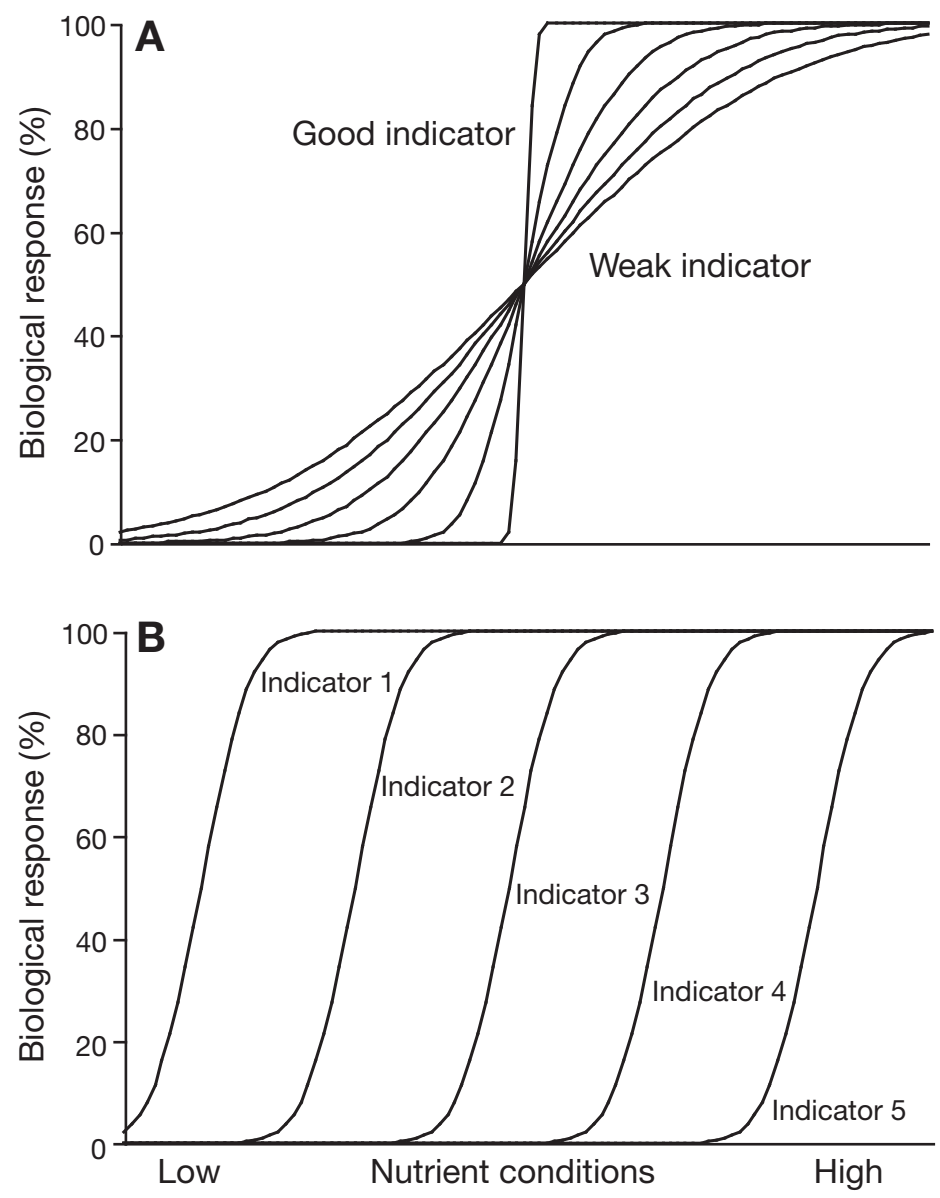

Fig. 1. Principles for good ecological indicators of phytoplankton composition in response to increasing nutrient pressure. (A) Indicators respond at the same nutrient level with different gradients. (B) Indicators respond at different nutrient levels with the same gradient 
Table 1: Characteristics of the 3 study areas (HELCOM 2002, 2004b; Helminen et al. 1998)

\begin{tabular}{|lccccrr|}
\hline & $\begin{array}{c}\text { Surface } \\
\text { area } \\
\left(\mathrm{km}^{2}\right)\end{array}$ & $\begin{array}{c}\text { Volume } \\
\left(\mathrm{km}^{3}\right)\end{array}$ & $\begin{array}{c}\text { Maximum } \\
\text { depth } \\
(\mathrm{m})\end{array}$ & $\begin{array}{c}\text { Average } \\
\text { depth } \\
(\mathrm{m})\end{array}$ & $\begin{array}{c}\text { Catchment } \\
\text { area } \\
\left(\mathrm{km}^{2}\right)\end{array}$ & $\begin{array}{c}\text { Freshwater } \\
\text { input } \\
\left(\mathrm{km}^{3} \mathrm{yr}^{-1}\right)\end{array}$ \\
\hline Gulf of Riga & 16330 & 424 & 62 & 26 & 128340 & 31 \\
Gulf of Finland & 29600 & 1100 & 123 & 38 & 412900 & 114 \\
Archipelago Sea & 9000 & 207 & 146 & 23 & 9000 \\
\hline
\end{tabular}

specific habitat, defined by salinity, and along a limited range of nutrient levels, while several community indicators will be needed to cover the entire realistic scale of nutrient levels (Fig. 1B).

In this study we present a generic statistical screening method that identifies phytoplankton species responding to different ranges of salinity, total nitrogen (TN) and total phosphorus (TP) based on their absence/presence. The objectives are: (1) to identify specific phytoplankton species or taxa responding to changes in nitrogen and phosphorus concentrations; and (2) to assess their potential as indicators for the trophic status of water bodies. The method was employed using phytoplankton data from the northern Baltic Sea, but it may also be applied to other phytoplankton databases.

\section{MATERIALS AND METHODS}

Study area. The Baltic Sea is a semi-

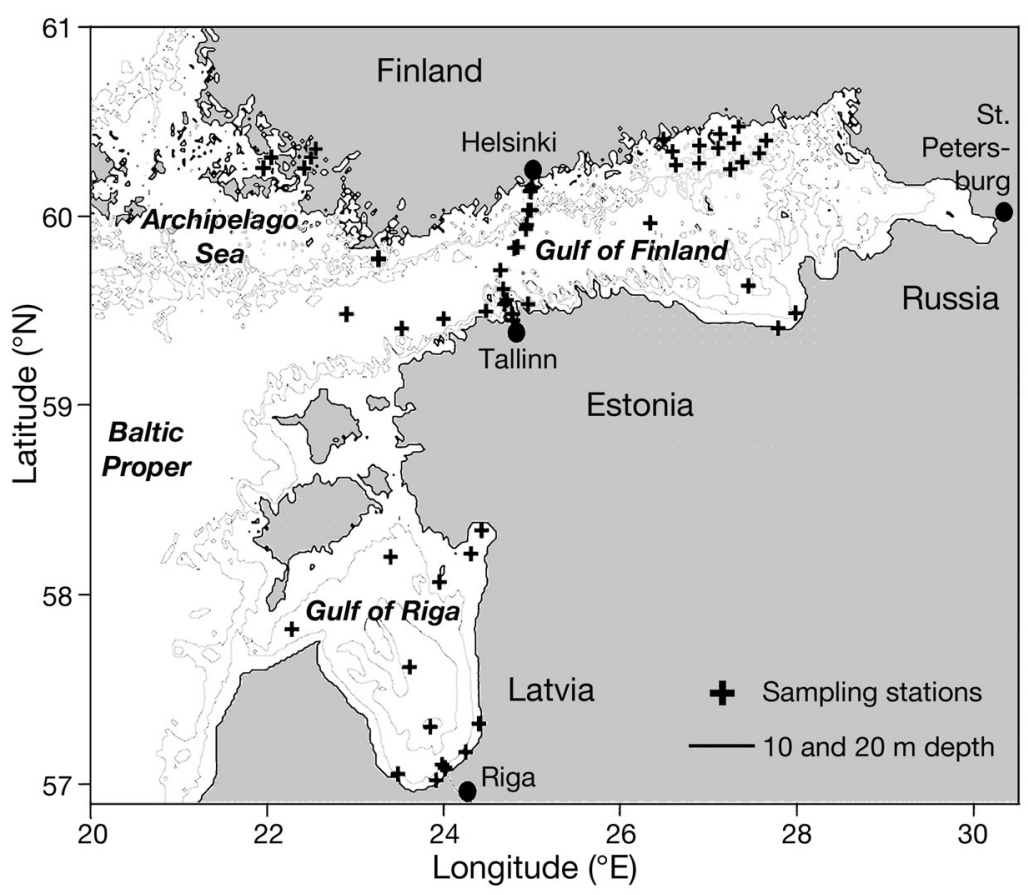

Fig. 2. Map of the study area with positions of sampling stations. Alg@line data sampled on ferry transect between Helsinki and Tallinn. Bathymetry data from Seifert \& Kayser (1995)

enclosed brackish water sea with a permanent halocline situated between 60 and $70 \mathrm{~m}$ depth and a seasonal thermocline between 10 and $30 \mathrm{~m}$. In the present study, hydrochemistry and phytoplankton data from the Gulf of Riga, Gulf of Finland and Archipelago Sea (Table 1) were investigated (Fig. 2).

The Gulf of Riga is connected to the Baltic Proper by the Irbe Sound to the west (35 $\mathrm{m}$ depth) and to the Gulf of Finland by the shallow Muhu sound (5 $\mathrm{m}$ depth) to the north. Surface salinity varies between 4 and 7 (Berzinsh 1995). Occasional intrusions of dense bottom water from the Baltic Proper form a halocline in the deeper parts. Approximately $86 \%$ of the freshwater input enters the southern part of the gulf (Berzinsh 1995), with the River Daugava, near Riga, contributing $20 \mathrm{~km}^{3} \mathrm{yr}^{-1}(65 \%)$ alone (HELCOM 2002). The water of the southern part, with relatively higher nutrient concentrations (Yurkovskis et al. 1993), is carried along the east coast although winds may cause changes from this general cyclonic circulation pattern.
The Gulf of Finland is a direct extension of the Baltic Proper and receives discharges from the largest river of the Baltic Sea, the Neva River, with a long-term mean of $78.5 \mathrm{~km}^{3} \mathrm{yr}^{-1}$ or $69 \%$ of the total freshwater input (HELCOM 2002). Discharges from the Neva River spread along the northern coast with the cyclonic circulation pattern and saltier surface water from the Baltic Proper enters along the southern coast. A heterogeneous pattern in nutrient concentrations along the northern coastline follows from the combined input of the Neva River and discharges from smaller rivers draining catchments largely comprised of forests (HELCOM 2002).

The Archipelago Sea encompasses the most islandrich archipelago of the Baltic Sea with over 6000 islands and $20000 \mathrm{~km}$ of coastline (HELCOM 2004b). It is generally shallow, with deeper areas found in the south-western part towards the Baltic Proper. There are no major rivers discharging into the Archipelago 
Sea but the small rivers vary substantially in flow and nutrient concentrations, leading to heterogeneous patterns in nutrient concentrations. North-south fractures in the bedrock facilitate exchanges between the Baltic Proper and the Bothnian Bay (Helminen et al. 1998). Due to the many small freshwater sources and complex bottom topography, the hydrography is diverse, particularly in the inner archipelago, with large differences in salinity and nutrient gradients.

Data collection and taxonomy. Long-term hydrochemistry and phytoplankton monitoring data (1970 to 2001) collected in the surface layer ( 0 to $10 \mathrm{~m}$ ) and analyzed according to the standardized HELCOM guidelines from Estonia, Finland and Latvia, as well as the Alg@line project (http://www4.fimr.fi/project/algaline/ algaline.htm) were integrated with a common species list for phytoplankton. The data represented integrated samples of 0 to $5 \mathrm{~m}$ (Finnish data), 0 to $10 \mathrm{~m}$ (Estonian and Latvian data) and $5 \mathrm{~m}$ discrete depth (Alg@line data). Data from 55 positions (14 Estonian, 19 Finnish, 8 Latvian and 14 Alg@line stations) located in the Gulf of Riga (13 stations), the Gulf of Finland (37 stations) and the Archipelago Sea (5 stations) were used. Only data from the productive period (March to September) were analyzed.

Phytoplankton analysis was carried out using inverted microscopes according to Utermöhl (1958) and HELCOM COMBINE recommendations (HELCOM 2001). Taxonomic identification was mostly carried out to species level. HELCOM phytoplankton courses and campaigns, arranged for taxonomists responsible for the identification of phytoplankton species, have ensured the compatability of the data.

The taxonomy of phytoplankton has undergone constant development from the earliest samples and as a consequence the number of species identified per sample has been gradually increasing during the first 2 decades of data collection and analysis. For Latvian data the average number of species per sample increased up to 1996. Consequently, data from Finland and Estonia before 1990 and data from Latvia before 1996 were not analyzed. Moreover, if the total number of species for a specific sample was $<10$, suggesting that the sample was only partially analyzed, observations from that sample were discarded.

Species present in at least $5 \%$ of the samples from the productive period were chosen as potential candidates for eutrophication indicator species. Some species were partially or entirely identified to genus and were consequently aggregated at this level. Specimens identified at the order level or with a morphological or size fraction only were not included in the analysis. Consequently, the list of potential indicators included species and genera only.
Phytoplankton species have developed different preferences for environmental conditions that favor growth and minimize loss; species experiencing optimal conditions are likely to increase their abundance at the expense of species experiencing sub-optimal conditions. Species with high abundance have higher probability of being identified in a sample. Although abundance or biomass proportion may be an appropriate indicator for species commonly encountered in samples, these are less appropriate for more rare species due to a high number of zero observations. In order to analyze a wide range of phytoplankton species, the presence/absence of specific species or genera was used as an indicator.

Presence-absence model. The presence of particular species/genera in a sample was analyzed in relation to the salinity and nutrient concentrations measured in the sample and the month of sampling, to account for seasonal succession of species and variation attributable to other factors such as light, temperature and stratification. The presence of a particular species in a sample is a Bernoulli variable with 2 possible outcomes, true or false, characterized by the parameter $p=\operatorname{Prob}$ (species present), i.e. the probability of finding the species in the sample. It was hypothesized that the probability had a natural seasonal distribution and was related to the salinity and nutrient level through a logistic link function, mapping the interval $0<p<1$ onto the whole real line (McCullagh \& Nelder 1989).

$$
\eta=g(p)=\log \left(\frac{p}{1-p}\right) \Leftrightarrow \quad p=g^{-1}(\eta)=\frac{\exp (\eta)}{1+\exp (\eta)}
$$

and the transform of the probability, $\eta$, was modeled as a function of

$$
\eta=m_{i}+c_{j}+a_{1} s+a_{2} n+a_{3} s^{2}+a_{4} n^{2}+a_{5} s n
$$

where $m_{i}$ described the seasonal variation (March to September: 9 levels), and $c_{j}$ described differences in the national monitoring program (Estonia, Finland, Latvia: 3 levels). This country-specific factor, $c_{j}$, was included to describe differences in recognizing different species/genera between the different monitoring programs. Within each of the 3 national monitoring programs, the phytoplankton samples were analyzed by several trained persons assumed to have a similar knowledge of phytoplankton taxonomy following the HELCOM guidelines, whereas differences between monitoring programs were expected. Alg@line data were analyzed by phytoplankton experts from Estonia and were pooled into the Estonian category for $c_{j}$. This factor implied that for particular species there was a higher or lower probability for identification, depending on which country analyzed the sample. 
The 5 remaining terms in Eq. (2) described a quadratic response surface in salinity $s$ and nutrient $n$, which was either total nitrogen (TN), total phosphorus (TP) or the TN:TP ratio. The response surface in $s$ and $n$ was restricted to have only one optimum for given values of either $s$ or $n$ through the constraints $a_{3}<0$ and $a_{4}<0$. This implied that for a given salinity the probability of presence could either: (1) increase monotonously with nutrient $n_{i}$ (2) decrease monotonously with $n_{\text {; }}$ or (3) have an optimum $n$ value. In the following, the term 'gradient' is used to describe the change in probability of presence $(p)$ with respect to nutrient $n$ for fixed salinity s. Outlier observations of $\mathrm{TN}>80 \mu \mathrm{M}, \mathrm{TP}>3 \mu \mathrm{M}, \mathrm{N}$ :P ratio $>80$, and salinities $<2$ and $>7$ were not used for estimating the response surfaces as they may have a considerable influence on the parameter estimates.

The analysis of species/genera presence in relation to seasonal variation, salinity and nutrient levels was carried out within the framework of Generalized Linear Models (McCullagh \& Nelder 1989) and the present model is a special case, also termed 'logistic regression'. The significance of $s$ and $n$ in the quadratic response surfaces was investigated by a likelihood ratio test imposing a zero constraint on both parameters simultaneously: $a_{1}=0$ and $a_{3}=0$ for salinity; $a_{2}=0$ and $a_{4}=0$ for nutrient level. All tests were carried out at a $5 \%$ significance level.

Model predictions. For each of the 3 combinations of salinity vs. TN, TP and TN:TP ratio, respectively, a polygon, or prediction surface, was manually drawn from scatter plots to encapsulate the bulk of data, ensuring that different regions were represented in the different parts of the prediction surface, i.e. no major part of the prediction surface included data from 1 region only. The probability $p$ of individual species being present was predicted for all combinations of $s$ and $n$ within these 3 polygons. The average change in probability over the 7 productive months with respect to changes in $n$ were calculated for all indicator candidates and the most responsive species were found for all combinations of $s$ and $n$.

The power of the different species to detect changes in nutrient levels or ratios was investigated by calculating the probability of detecting a significant change when comparing 2 groups of observations. Two binomial distributions, $\mathrm{B}\left(n, p_{1}\right)$ and $\mathrm{B}\left(n, p_{2}\right)$, were simulated 1000 times for $n=10,20,30,40 \& 50$ and for differences between $p_{1}$ and $p_{2}$ ranging from 0.10 to 0.80 . The probability of detecting a difference (i.e. the power) was calculated as the number of significant trials $\times 10^{-3}$, and differences $p_{1}-p_{2}$ necessary to obtain a power of $80 \%$ were calculated for the different sample sizes. These differences $p_{1}-p_{2}$ for different sample sizes were compared to predicted probabilities from the response surfaces corresponding to changing the levels of TN by $20 \%$, TP by $30 \%$ and TN:TP ratio by $30 \%$, for fixed salinities. These values of reduced nutrient levels correspond approximately to the observed changes resulting from nutrient management in a large coastal ecosystem (Carstensen et al. 2006).

\section{RESULTS}

\section{Number of samples}

A total of 2217 phytoplankton samples were included in the study, 490 observations from the Gulf of Riga, 1643 observations from the Gulf of Finland and 84 observations from the Archipelago Sea. Most samples were from August (476 observations) and the least samples were from March (87 observations). One station was represented by 151 samples but most stations had $<50$ observations. Out of the 2217 phytoplankton samples, 1372 had observations of salinity and TN, 1419 had observations of salinity and TP, and 1369 had observations of salinity and TN:TP ratio. After removing outliers prior to modeling, these numbers were reduced to 1343, 1395, and 1341 observations respectively. There was a reasonably homogeneous representation of salinity and nutrient observations within the polygons constructed for predicting response surfaces for the presence of species/genera (Fig. 3).

\section{Species composition}

The list of most common phytoplankton species included 76 species/genera with an almost equal majority of cyanobacteria and diatoms (Table 2). Dinoflagellates, chlorophytes, and chryptophytes were represented by 13, 12 and 6 species/genera respectively. There were significant differences between the species/genera identified in the different national monitoring programs, taking variations due to salinity, nutrients and month of sampling into account; these were most pronounced for Aphanocapsa sp., Dinobryon faculiferum, and Planktolyngbya contorta observed in Estonian monitoring data only, Hemiselvis virescens observed in Finnish and Alg@line data only, and Oocystis solitaria observed in Latvian monitoring data only. In fact, for all but 7 species/ genera (Achnanthes taeniata, Anabaena sp., Chaetoceros ceratosporus, Chaetoceros subtilis, Eutreptiella sp., Prorocentrum minimum, and Skeletonema costatum) the presence was significantly related to the national monitoring program for all 3 nutrient mod- 

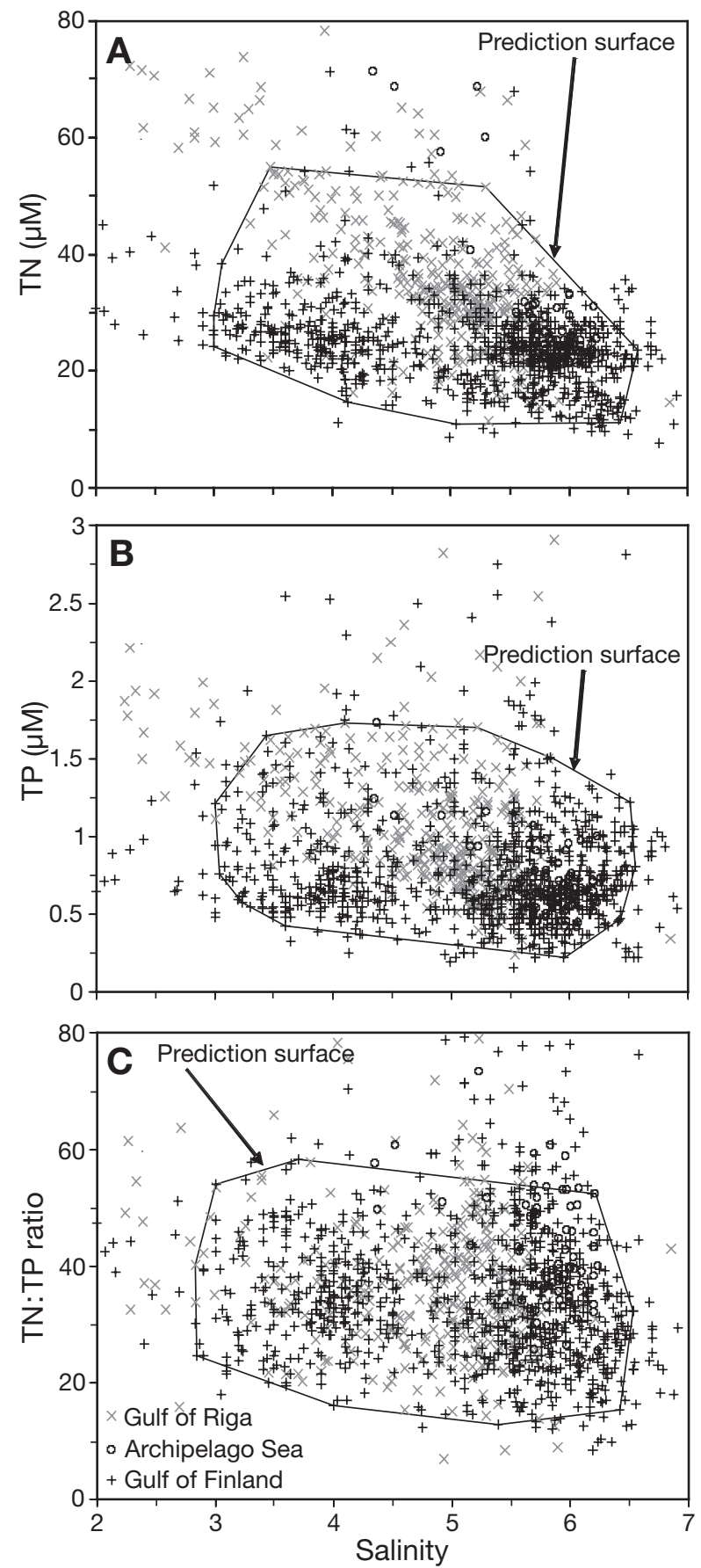

Fig. 3. Scatter plots of salinity and: (A) TN; (B) TP; (C) TN:TP observations used to model presence of species/genera. Probabilities of presence were predicted for values within prediction surfaces

els. For many of the species/genera $c_{j}$ was the most significant factor in Eq. (2). The seasonal variation was another important factor except for 13 species/ genera that did not consistently have a significant monthly variation for the 3 nutrient models.

\section{Responses to salinity and nutrient levels}

The presence of most species was significantly related to salinity but 28 species/genera did not respond significantly in the 3 nutrient models. Approximately half of the species/genera responded significantly to TN levels (34 out of 76), TP levels (32 out of 76), and $\mathrm{N}$ :P ratio (42 out of 76 ), but there were differences in that some species/genera responded to TN only, some to TP only and some to N:P ratio only (Table 3). The 18 species/genera that did not respond significantly to changing nutrient levels were mainly diatoms (Achnanthes taeniata, Chaetoceros holsaticus, Licmophora sp., Nitzschia acicularis, Rhoicosphenia abbreviate, Thalassiosira baltica), besides chlorophytes (Chlamydomonas sp., Dictyosphaerium ehrenbergianum, and Oocystis solitaria), cyanobacteria (Anabaena lemmermannii, Microcystis sp., and Woronichinia sp.), dinoflagellates (Heterocapsa triquetra, Oblea rotunda, Peridiniella catenata, Prorocentrum minimum), and Eutreptiella sp. Moreover, the significance of salinity was mostly higher than TN (51 out of 76), TP (53 out of 76) and N:P (55 out of 76). However, it should be stressed that these tests were based on a large number of observations with large ranges in nutrient levels and that, on average, $5 \%$ of the tests may turn out as significant simply by chance. Response surfaces and seasonal distribution in probability of presence for all 76 taxonomical units may be found at: www.dmu.dk/ International/Water/REBECCA/BalticSpecies.

Only 6 species/genera (Chroococcus sp., Chrysochromulina sp., Eutreptiella sp., Heterocapsa rotundata, Lemmermanniella sp., and Planktothrix agardhii) had gradients in the probability of presence exceeding $30 \%$ (an explanation for this value is given in subsection 'Power analysis' below) for a given salinity and ranges of TN within the prediction surface (Fig. 3). The maximum gradients in probability of presence for the entire range of salinity included 3 of these species/ genera (Fig. 4A). Probability of presence of Chrysochromulina sp. increased from about $50 \%$ at low TN concentrations to about $90 \%$ at high TN concentrations (Fig. 5) independently of the salinity level (salinity not significant; Table 3). Probability of presence of $H$. rotundata also increased with $\mathrm{TN}$ concentrations but was most pronounced at low salinity levels. $P$. agardhii was mostly present at low salinities with an optimum probability of presence around $27 \mu \mathrm{M}$ TN.

For the considered ranges of TP only 3 species/genera (Anabaena sp., Heterocapsa rotundata, and Planktothrix agardhii) had gradients in probability of presence larger than $30 \%$ (see explanation in subsection 'Power analysis' below) for the various salinity levels, and these species/genera all represented maximum gradients for different ranges of salinity (Fig. 4B). 
Table 2. Potential eutrophication indicators $(n=76)$ based on species and genera, grouped according to their division, present in $>5 \%$ of samples taken during productive season (March-September). Chrysochromulina sp. (member of Haptophyta division) and Eutreptiella sp. (member of Euglenophyta division) were also potential indicators but not included in table, as they were the only representatives of their division

\begin{tabular}{|c|c|c|c|c|}
\hline Cyanophyta & Chryptophyta & Dinophyta & Heterokontophyta & Chlorophyta \\
\hline $\begin{array}{l}\text { Anabaena lemmermannii } \\
\text { Anabaena sp. } \\
\text { Aphanizomenon flos-aquae } \\
\text { Aphanizomenon gracile } \\
\text { Aphanocapsa sp. } \\
\text { Aphanothece sp. } \\
\text { Chroococcus sp. } \\
\text { Cyanodictyon sp. } \\
\text { Lemmermanniella sp. } \\
\text { Merismopedia punctata } \\
\text { Merismopedia tenuissima } \\
\text { Microcystis sp. } \\
\text { Nodularia spumigena } \\
\text { Planktolyngbya contorta } \\
\text { Planktolyngbya sp. } \\
\text { Planktothrix agardhii } \\
\text { Pseudanabaena limnetica } \\
\text { Snowella lacustris } \\
\text { Snowella sp. } \\
\text { Woronichinia sp. }\end{array}$ & $\begin{array}{l}\text { Cryptomonas sp. } \\
\text { Hemiselmis sp. } \\
\text { Hemiselmis virescens } \\
\text { Plagioselmis prolonga } \\
\text { Rhodomonas sp. } \\
\text { Teleaulax sp. }\end{array}$ & $\begin{array}{l}\text { Amphidinium crassum } \\
\text { Amphidinium sphenoides } \\
\text { Dinophysis acuminata } \\
\text { Dinophysis rotundata } \\
\text { Gymnodinium sp. } \\
\text { Heterocapsa rotundata } \\
\text { Heterocapsa triquetra } \\
\text { Oblea sp. } \\
\text { Peridiniella catenata } \\
\text { Peridinium sp. } \\
\text { Prorocentrum balticum } \\
\text { Prorocentrum minimum } \\
\text { Scrippsiella hangoei }\end{array}$ & $\begin{array}{l}\text { Achnanthes taeniata } \\
\text { Actinocyclus octonarius } \\
\text { Asterionella formosa } \\
\text { Chaetoceros ceratosporus } \\
\text { Chaetoceros danicus } \\
\text { Chaetoceros holsaticus } \\
\text { Chaetoceros subtilis } \\
\text { Chaetoceros wighamii } \\
\text { Coscinodiscus granii } \\
\text { Cylindrotheca closterium } \\
\text { Diatoma tenuis } \\
\text { Dinobryon faculiferum } \\
\text { Fragilaria sp. } \\
\text { Licmophora sp. } \\
\text { Melosira arctica } \\
\text { Navicula sp. } \\
\text { Nitzschia acicularis } \\
\text { Nitzschia longissima } \\
\text { Pseudopedinella sp. } \\
\text { Rhoicosphenia abbreviata } \\
\text { Skeletonema costatum } \\
\text { Thalassiosira baltica } \\
\text { Thalassiosira levanderi }\end{array}$ & $\begin{array}{l}\text { Chlamydomonas sp. } \\
\text { Dictyosphaerium } \\
\text { ehrenbergianum } \\
\text { Dictyosphaerium sp. } \\
\text { Koliella sp. } \\
\text { Monoraphidium contortum } \\
\text { Oocystis borgei } \\
\text { Oocystis lacustris } \\
\text { Oocystis solitaria } \\
\text { Oocystis submarina } \\
\text { Planktonema lauterbornii } \\
\text { Pyramimonas sp. } \\
\text { Scenedesmus communis }\end{array}$ \\
\hline
\end{tabular}

There was low probability of observing Anabaena sp. for high salinity and TP levels, whereas the probability of presence increased to ca. $50 \%$ for low salinity and TP levels (Fig. 6). The response surface for $H$. rotundata using TP concentrations was very similar to that obtained by TN concentrations, whereas the response surface for $P$. agardhii did not have as marked an optimum response for TP as for TN, and mostly showed decreasing probability of presence with increasing TP concentrations.

Changes in the N:P ratio with ranges according the prediction surface (Fig. 3) only gave probability gradients exceeding $30 \%$ (see explanation in subsection 'Power analysis') for 3 genera (Gymnodinium sp., Hemiselmis sp., and Teleaulax sp.). These 3 genera represented maximum gradients for low and high salinity whereas Scrippsiella hangoei had the largest, although moderate, response for medium salinity (Fig. 4C). Gymnodinium sp. were almost absent for low levels of salinity increasing to about $50 \%$ probability of presence for high salinity and N:P ratio (Fig. 7). The probability of observing Hemiselmis sp. in a sample was approximately $50 \%$ for most combinations of salinity and N:P, but decreased to about $20 \%$ for low salinity and high N:P ratio. Teleaulax sp. was similarly present in about $50 \%$ of the samples for most of the prediction surface, increasing to ca. $80 \%$ for high salinity and low N:P ratio.
There were commonalities in the species/genera responding significantly and considerably to changing TN and TP concentrations, mainly due to a strong correlation between $\mathrm{TN}$ and $\mathrm{TP}$ observations $(\mathrm{r}=0.60)$. Similar seasonal patterns were obtained by means of the 2 models for the 4 species/genera responding to changing TN and TP levels with $>30 \%$ probability of presence (Fig. 8). Anabaena sp. had the most pronounced seasonal pattern with highest probability of presence from July to September. Chrysochromulina sp. and Heterocapsa rotundata generally became more present in the samples from spring to summer, whereas Planktothrix agardhii had the lowest probabilities of presence in April and May.

\section{Power analysis}

The simulation study showed that there should be a difference in probability of presence of at least $59 \%$, $44 \%, 35 \%, 31 \%$, \& $28 \%$ for sample sizes of $10,20,30$, $40 \& 50$ respectively, in order to obtain a power $>80 \%$ (Fig. 9). With realistic sample sizes of 40 to 50 observations, probability gradients should be ca. $30 \%$, which is the value used for assessing the appropriateness of different indicator species above. Examining the average gradient of the response surfaces over the 7 pro- 
Table 3: Significance of relationship $\left({ }^{*}: \mathrm{p}<0.05_{i^{* *}}: \mathrm{p}<0.01_{i}{ }^{* * *} \mathrm{p}<0.001\right)$ to salinity (s) and nutrient (n) for the 3 different response surfaces. Only species/genera that responded significantly $(p<0.05)$ to any of the nutrient variables are shown. Shapes of significant response within the response surfaces are $(+)$ increasing, $(-)$ decreasing, and $(\cap)$ optimum value. ns: not significant

\begin{tabular}{|c|c|c|c|c|c|c|}
\hline \multirow[t]{2}{*}{ Species/genus } & \multicolumn{2}{|c|}{ TN model } & \multicolumn{2}{|c|}{ TP model } & \multicolumn{2}{|c|}{$\mathrm{N}: \mathrm{P}$ model } \\
\hline & $\mathrm{s}$ & $\mathrm{n}$ & $\mathrm{s}$ & $\mathrm{n}$ & $\mathrm{s}$ & $\mathrm{n}$ \\
\hline Actinocyclus octonarius & $\cap{ }^{*}$ & $+{ }^{* *}$ & $\cap$ & $+^{* *}$ & $\cap^{* * *}$ & $-{ }^{* *}$ \\
\hline Amphidinium crassum & $\cap$ & ns & ns & & ns & ns \\
\hline Amphidinium sphenoides & $+{ }^{* *}$ & ns & $+^{* * *}$ & ns & $+{ }^{* * *}$ & $\cap^{* * *}$ \\
\hline Anabaena sp. & $-{ }^{* * *}$ & $-{ }^{* *}$ & $-{ }^{* * *}$ & $-{ }^{* * *}$ & $-{ }^{* * *}$ & $+^{* * *}$ \\
\hline Aphanizomenon flos-aquae & ns & $-{ }^{* * *}$ & ns & $\mathrm{ns}$ & ns & $-{ }^{*}$ \\
\hline Aphanizomenon gracile & $-{ }^{* * *}$ & ns & $--^{* * *}$ & $--^{* * *}$ & $-{ }^{* * *}$ & $++^{* * *}$ \\
\hline Aphanocapsa sp. & & $-^{* * *}$ & $-{ }^{* *}$ & $++^{* * *}$ & ns & $\cap^{* *}$ \\
\hline Aphanothece sp. & $\mathrm{ns}$ & $\cap{ }^{*}$ & ns & ns & ns & ns \\
\hline Asterionella formosa & $--^{* * *}$ & $-{ }^{* *}$ & $-{ }^{* * *}$ & $\mathrm{~ns}$ & $-{ }^{* * *}$ & $\cap^{*}$ \\
\hline Chaetoceros ceratosporus & $-{ }^{* * *}$ & $-\quad *$ & $--^{* * *}$ & $-{ }^{* *}$ & $-{ }^{* * *}$ & ns \\
\hline Chaetoceros danicus & ns & ns & ns & $-{ }^{*}$ & ns & $++^{* * *}$ \\
\hline Chaetoceros subtilis & $-{ }^{* * *}$ & $\cap{ }^{*}$ & $--^{* * *}$ & $\cap^{* *}$ & $-{ }^{* * *}$ & ns \\
\hline Chaetoceros wighamii & $\cap{ }^{* *}$ & ns & $-{ }^{* *}$ & $--^{* *}$ & $\cap^{*}$ & ns \\
\hline Chroococcus sp. & $--^{* * *}$ & $\cap^{* * *}$ & $\cap^{* * *}$ & $\cap^{* * *}$ & ns & $++^{* * *}$ \\
\hline Chrysochromulina sp. & ns & $+^{* * *}$ & $\cap^{* * *}$ & $++^{* * *}$ & ns & $+{ }^{*}$ \\
\hline Coscinodiscus granii & $\mathrm{ns}$ & ns & ns & $+^{* * *}$ & $++^{* *}$ & $\cap^{* *}$ \\
\hline Cryptomonas sp. & $-{ }^{* * *}$ & $+{ }^{* *}$ & $-{ }^{* * * *}$ & ns & $-{ }^{* * *}$ & $+{ }^{*}$ \\
\hline Cyanodictyon sp. & $+^{* * *}$ & $+{ }^{* *}$ & $\cap^{* * *}$ & $\cap^{* * *}$ & $\cap{ }^{*}$ & $+^{* * *}$ \\
\hline Cylindrotheca closterium & $\cap^{* *}$ & $\cap^{* * *}$ & $\cap^{* * *}$ & $\mathrm{~ns}$ & $\cap^{* * *}$ & $\cap{ }^{*}$ \\
\hline Diatoma tenuis & $-^{* * *}$ & ns & $-{ }^{* * *}$ & $-{ }^{* *}$ & $-{ }^{* * *}$ & $++^{* *}$ \\
\hline Dictyosphaerium sp. & $-{ }^{* *}$ & $+^{* * *}$ & $-{ }^{* * *}$ & ns & $-{ }^{* * *}$ & $\mathrm{~ns}$ \\
\hline Dinobryon faculiferum & $+^{* * *}$ & ns & $+^{* * *}$ & $-{ }^{*}$ & $+^{* * *}$ & ns \\
\hline Dinophysis acuminata & $+^{* * *}$ & $-{ }^{* * *}$ & $+^{* * *}$ & $-{ }^{* * *}$ & $+^{* * *}$ & $+{ }^{*}$ \\
\hline Dinophysis rotundata & ns & $-{ }^{*}$ & ns & ns & ns & ns \\
\hline Fragilaria sp. & $--^{* * *}$ & ns & $--^{* * *}$ & ns & $-{ }^{* * *}$ & $+{ }^{*}$ \\
\hline Gymnodinium sp. & $++^{* * *}$ & $+* * *$ & $++^{* * *}$ & ns & $+{ }^{* * *}$ & $+^{* * *}$ \\
\hline Hemiselmis sp. & $+\quad * *$ & $++^{* * *}$ & $+{ }^{* *}$ & $+^{* * *}$ & $+{ }^{* * *}$ & $-{ }^{* *}$ \\
\hline Hemiselmis virescens & $++^{* * *}$ & $\cap^{* * *}$ & $+^{* * *}$ & ns & $+{ }^{* * *}$ & $+^{* * *}$ \\
\hline Heterocapsa rotundata & $++^{* * *}$ & $++^{* * *}$ & $++^{* * *}$ & $++^{* * *}$ & $+{ }^{* * *}$ & ns \\
\hline Koliella sp. & ns & ns & ns & $+{ }^{*}$ & ns & ns \\
\hline Lemmermanniella sp. & $\cap{ }^{*}$ & $-{ }^{* * *}$ & $\cap^{* * *}$ & ns & $++^{* *}$ & $-{ }^{* *}$ \\
\hline Melosira arctica & $-{ }^{* * *}$ & & $-{ }^{* * *}$ & $\mathrm{~ns}$ & $-{ }^{* * *}$ & $\cap^{* * *}$ \\
\hline Merismopedia punctata & ns & $\mathrm{ns}$ & $\mathrm{ns}$ & $+^{* * *}$ & ns & $-{ }^{* *}$ \\
\hline Merismopedia tenuissima & $-{ }^{* *}$ & & ns & $\mathrm{ns}$ & $-{ }^{* *}$ & \\
\hline Monoraphidium contortum & $-{ }^{* * *}$ & ns & & $+{ }^{*}$ & $-{ }^{* * *}$ & \\
\hline Navicula sp. & ns & $+{ }^{*}$ & ns & ns & $-{ }^{* *}$ & ns \\
\hline Nitzschia longissima & $--^{* * *}$ & $-{ }^{* *}$ & $-{ }^{* * *}$ & $\mathrm{~ns}$ & $-{ }^{* * *}$ & $-{ }^{* * *}$ \\
\hline Nodularia spumigena & ns & ns & & $-{ }^{* *}$ & ns & $+^{* * *}$ \\
\hline Oocystis borgei & $\cap^{* * *}$ & ns & $\cap^{* * *}$ & $\cap^{* * *}$ & $\cap^{* * *}$ & $+^{* * *}$ \\
\hline Oocystis lacustris & $\cap^{* * *}$ & ns & $\cap^{* * *}$ & ns & $\cap^{* * *}$ & $\cap^{* * *}$ \\
\hline Oocystis submarina & $\cap^{* * *}$ & ns & $-^{* * *}$ & ns & $-{ }^{* *}$ & $+{ }^{*}$ \\
\hline Peridinium sp. & & $-^{* * *}$ & & $--^{* * *}$ & ns & ns \\
\hline Plagioselmis prolonga & $+^{* * *}$ & ns & $++^{* * *}$ & $+^{* * *}$ & $+^{* * *}$ & ns \\
\hline Planktolyngbya contorta & $\cap^{* * *}$ & $\cap^{* * *}$ & $+^{* * *}$ & ns & $+{ }^{* * *}$ & $\cap^{* * *}$ \\
\hline Planktolyngbya sp. & ns & ns & ns & $--^{* * *}$ & ns & $+^{* * *}$ \\
\hline Planktonema lauterbornii & $\mathrm{ns}$ & $\mathrm{ns}$ & & $-{ }^{* *}$ & $-{ }^{*}$ & $+{ }^{*}$ \\
\hline Planktothrix agardhii & $-{ }^{* * *}$ & $\cap^{* *}$ & $-{ }^{* * *}$ & $\mathrm{~ns}$ & $-{ }^{* * *}$ & $\cap{ }^{*}$ \\
\hline Prorocentrum balticum & $\cap^{* * *}$ & $+^{* * *}$ & $\cap^{* * *}$ & ns & $\cap^{* * *}$ & $+{ }^{* *}$ \\
\hline Pseudanabaena limnetica & ns & ns & $\mathrm{ns}$ & $--^{* * *}$ & ns & ns \\
\hline Pseudopedinella sp. & $\cap^{* * *}$ & $+^{* * *}$ & $\cap^{* * *}$ & ns & $\cap^{* * *}$ & ns \\
\hline Rhodomonas sp. & $+{ }^{* *}$ & ns & $+^{* * *}$ & $+^{* * *}$ & ns & $-{ }^{* * *}$ \\
\hline Scenedesmus communis & $--^{* * *}$ & ns & $--^{* * *}$ & ns & $-{ }^{* * *}$ & $+{ }^{* *}$ \\
\hline Scrippsiella hangoei & ns & $-^{* * *}$ & $+{ }^{* *}$ & $++^{* *}$ & ns & $--^{* * *}$ \\
\hline Skeletonema costatum & & $+\quad *$ & $+\quad *$ & ns & ns & $\cap^{*}$ \\
\hline Snowella lacustris & $-^{* * *}$ & $+* *$ & $-^{* * *}$ & $+{ }^{*}$ & $-{ }^{* * *}$ & ns \\
\hline Snowella sp. & ns & & ns & ns & $\cap^{*}$ & $\cap^{* *}$ \\
\hline Teleaulax sp. & $+^{* * *}$ & ns & $+^{* * *}$ & $+^{* * *}$ & $+^{* * *}$ & $-{ }^{* * *}$ \\
\hline Thalassiosira levanderi & ns & $+{ }^{*}$ & ns & ns & ns & $\mathrm{ns}$ \\
\hline
\end{tabular}

ductive months for decreasing TN concentrations of $20 \%$ revealed that only 1 species had sufficient power to detect a change in the probability of presence (Planktothrix agardhii) and that no species/genera was capable of detecting decreases of $30 \%$ in TP or N:P levels. In fact, $P$. agardhii had sufficient power for a very small part of the prediction surface only (salinity between 3.2 and 3.4; TN between 40 and $44 \mu \mathrm{M}$ ) and given the highest sample size simulated $(n=50)$. Similarly, the few species that had gradients in probability of presence $>30 \%$ have sufficient power with a sample size of 40 to 50 (in each period) provided that decreases in $\mathrm{TN}$, TP and N:P are similar to the ranges of the prediction surfaces, i.e. changes of $>50 \%$.

\section{DISCUSSION}

\section{Phytoplankton as indicators of nutrient stress}

In this study we have developed and tested a statistical screening tool to detect phytoplankton species that respond significantly to elevated nutrient status. The method, as such, is generic and can be applied to phytoplankton monitoring data from other regions as well. Starting with a list of the 76 most common phytoplankton species/genera, only half of these responded significantly to changing nutrient levels by increasing or decreasing presence, and out of these only 4 species had substantial responses in the probability of presence (gradients $>30 \%$ ). Finally, only one species (Planktothrix agardhii) had sufficient probability gradient to allow for detection of the effect of realistic declines in TN concentrations, and this only for a very limited range of salinity and TN levels. In fact, $P$. agardhii is the only species of the 76 candidates to be characterized as an indicator of eutrophication for the study area in a comprehensive compilation of phytoplankton species in the Baltic Sea (HELCOM 2004a). Large summer blooms of $P$. agardhii have been reported in the 
eastern Gulf of Finland near the Neva estuary in the Baltic Sea (Kauppila et al. 1995). Phytoplankton samples dominated by P. agardhii in the Stockholm Archipelago in the pre-wastewater treatment period and eutrophic lakes have led to the suggestion that this filamentous species was indicative of a nutrient-rich environment (Johansson \& Wallström 2001). Potential links to eutrophication have not been reported for the other species with substantial gradients (Figs. 5-7) in the Baltic Sea area. This could imply that the presence of specific phytoplankton species is not affected by nutrient enrichment.
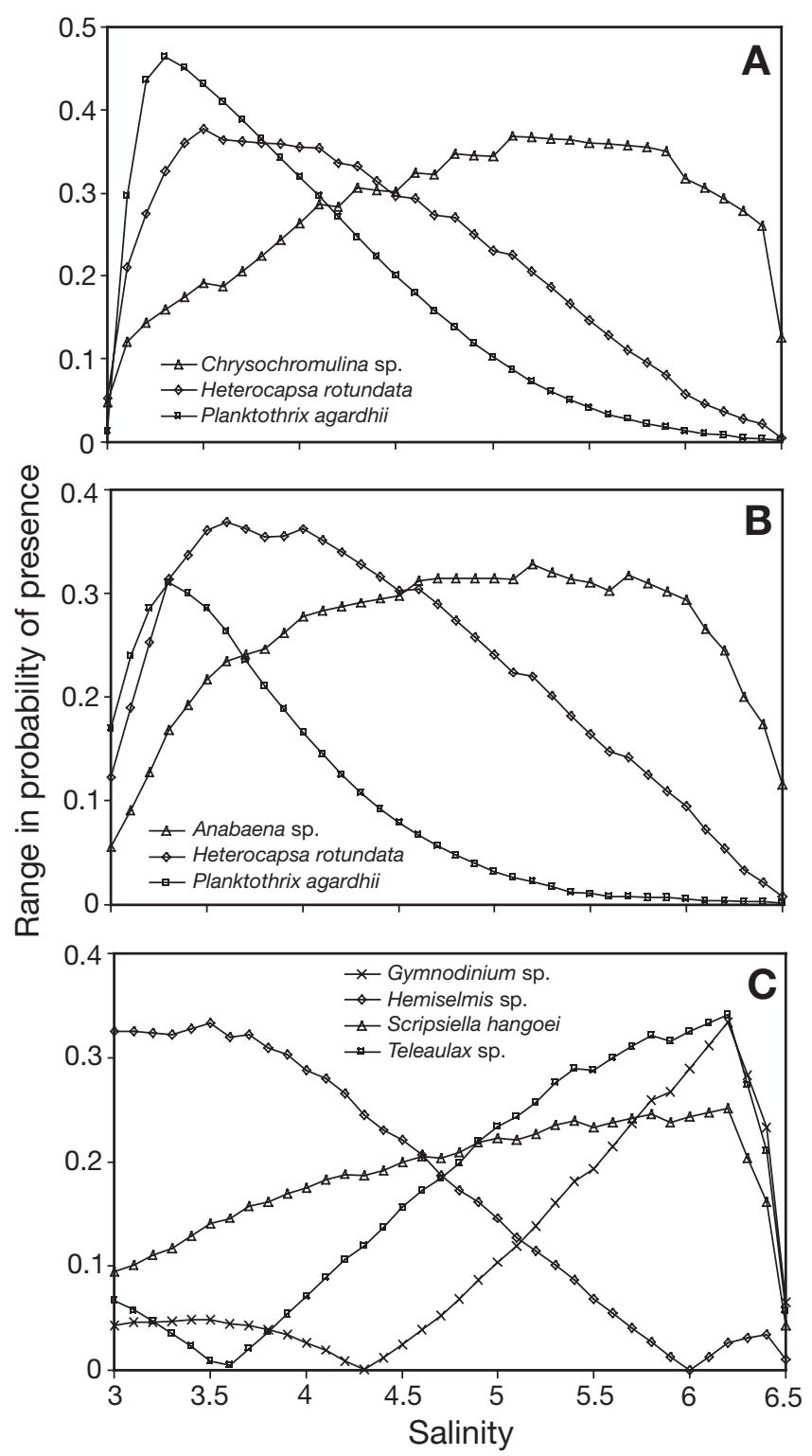

Fig. 4. Maximum difference in the probability of presence (max-min) over ranges of: (A) $\mathrm{TN}_{i}$ (B) $\mathrm{TP}_{i}$ (C) TN:TP for various salinity levels. Only species/genera with largest difference of all are shown

\section{Structuring mechanisms}

Phytoplankton species have developed different strategies that should favor or disfavor them at certain nutrient levels. For example, dinoflagellates generally have higher half-saturation constant $\left(K_{\mathrm{s}}\right)$ values for
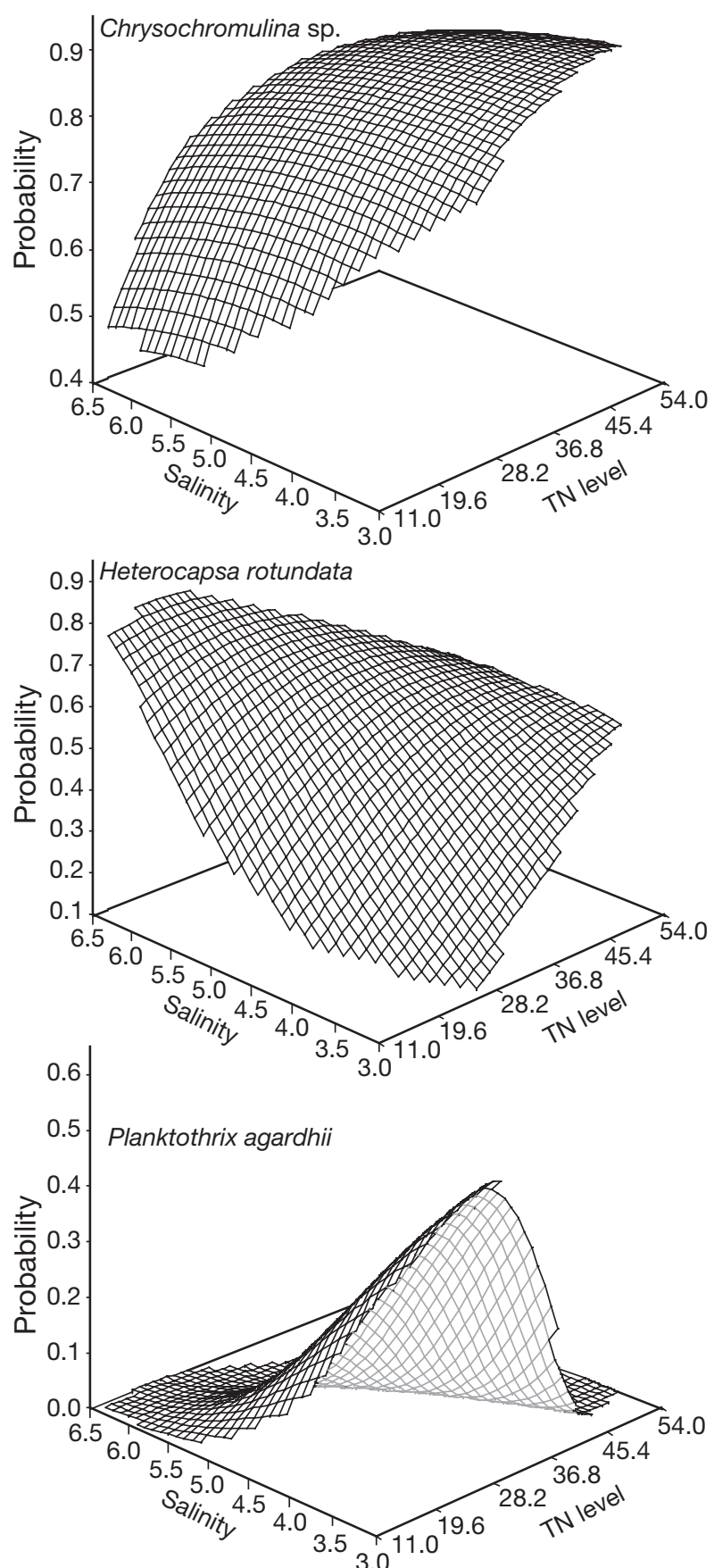

Fig. 5. Estimated response surfaces averaged over productive months (March to September) for probability of presence related to salinity and TN concentration. Response surfaces are shown for the 3 species/genera most indicative of changing TN levels 
nutrient uptake and Smayda (1997) has suggested that dinoflagellates have evolved 4 adaptations to compensate for this: nutrient retrieval migration, mixotrophic nutritional tendencies, allelochemically enhanced interspecific competition, and allelopathic, anti-preda-
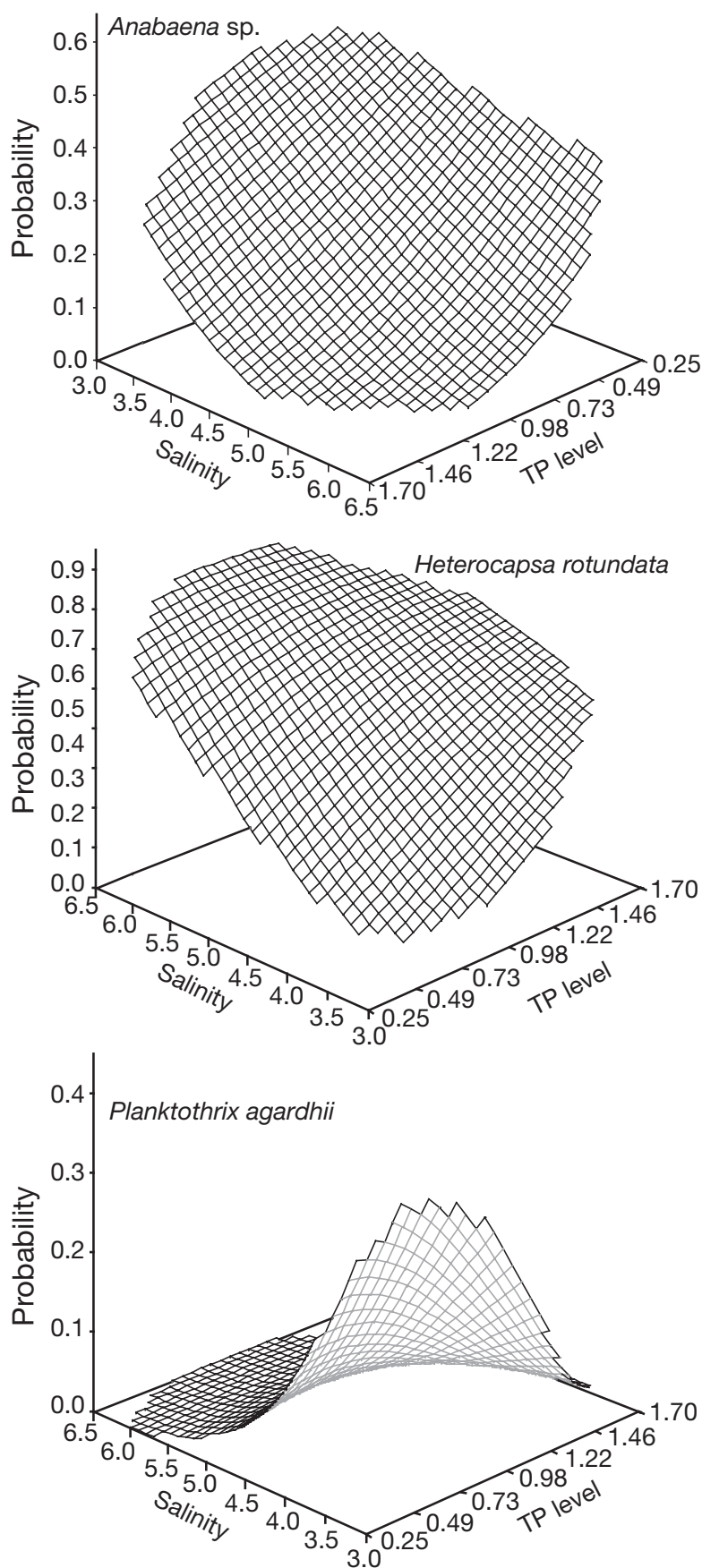

Fig. 6. Estimated response surfaces averaged over productive months (March to September) for probability of presence related to salinity and TP concentration. Response surfaces are shown for the 3 species/genera most indicative of changing TP levels. Note that for Anabaena sp. the direction of the axes for salinity and TP has been reversed tion defense mechanisms. Similarly, cyanobacteria have the ability to fix nitrogen and adjust their buoyancy (Oliver 1994) and toxic species like Chrysochromulina polylepis may adjust the production of allelochemicals according to the availability of nutrients (Johansson \& Granéli 1999). Species-specific grazing rates for different types of grazers (e.g. Pires et al. 2005) add another dimension to this complexity.
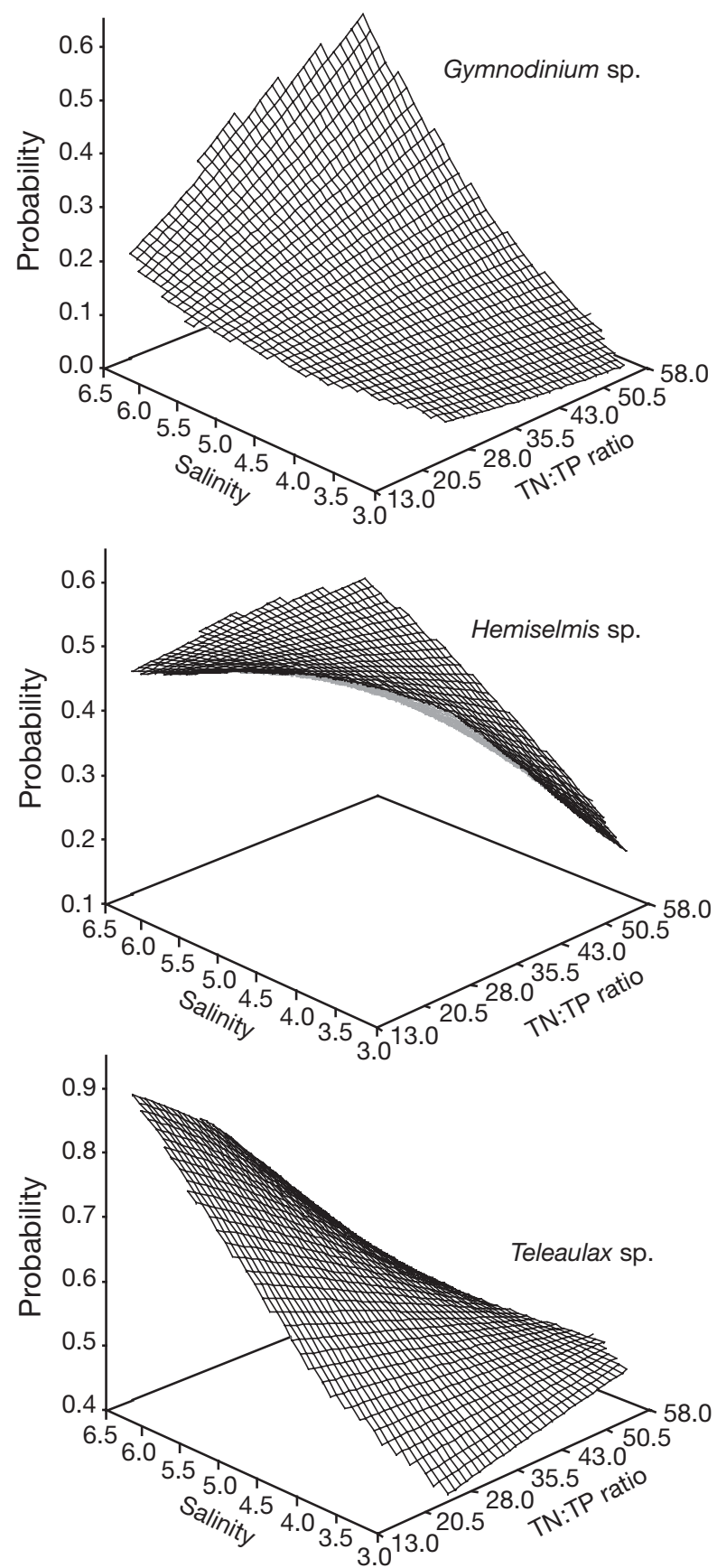

Fig. 7. Estimated response surfaces averaged over productive months (March to September) for probability of presence related to salinity and TN:TP ratio. Response surfaces shown for 3 species/genera most indicative of changing TN:TP ratios 
Smayda \& Reynolds (2001) developed a life-form concept suggesting that eutrophic coastal waters would be dominated mainly by gymnodinioids, peridinioids and prorocentroids. However, as they argue, there is a strong stochastic element in the selection process of different life-forms that will not guarantee the inclusion or exclusion of certain life-forms, or species/genera for that matter, in a given habitat. Our study supports this conclusion by showing that a major part of the investigated species actually do respond to changing nutrient levels, but also that variation is so substantial that we are unlikely to find species/genera that respond promptly (see Fig. 1). It is unlikely that phytoplankton species should have a threshold-type of response to changing $\mathrm{N}$ and $\mathrm{P}$ concentrations as long as $\mathrm{N}$ and $\mathrm{P}$ are kept at moderate, realistic levels. Species unable to compete for nutrients at a wide range of nutrient levels are unlikely to survive in the course of phytoplankton evolution. However, species-specific differences in nutrient and micro-nutrient requirements could potentially lead to large gradients in the response surfaces once a limiting element becomes depleted.

\section{Nutrient requirements}

Fundamental changes in phytoplankton community structure might occur if $\mathrm{Si}$ becomes depleted, because diatoms have a much higher $\mathrm{Si}$ requirement than other species. In the Baltic Sea area, Si concentrations are generally high and Si-limitation has not yet been recorded, except for possible short-term shortages during the spring bloom (Yurkovskis 2004). This therefore suggests that our results are not biased by Si-limitation. The variation in $\mathrm{N}$ and $\mathrm{P}$ requirements between species is less than for $\mathrm{Si}$ (species-specific optimum N:P ratio may vary up to a factor of 6 ; see Rhee \& Gotham 1980, Klausmeier et al. 2004) but the diversity of the phytoplankton community may still allow many different species to coexist although the available nutrients are not optimal (Tilman et al. 1982). This suggests that shifting between N- and Plimitation may not necessarily induce abrupt changes to phytoplankton community structure, which were not evident from the present study. Sediment records from the Baltic Proper suggest that the open part of the Baltic Sea has been N-limited for at least $7000 \mathrm{yr}$ (Bianchi et al. 2000) switching to P-limitation in inner estuaries (Pitkanen \& Tamminen 1995). The stations sampled in the present study were all coastal or from outer estuaries and therefore the majority of observations would reflect conditions of nitrogen limitation. Consequently, changes in the phytoplankton community due to an overall shift between nitrogen and
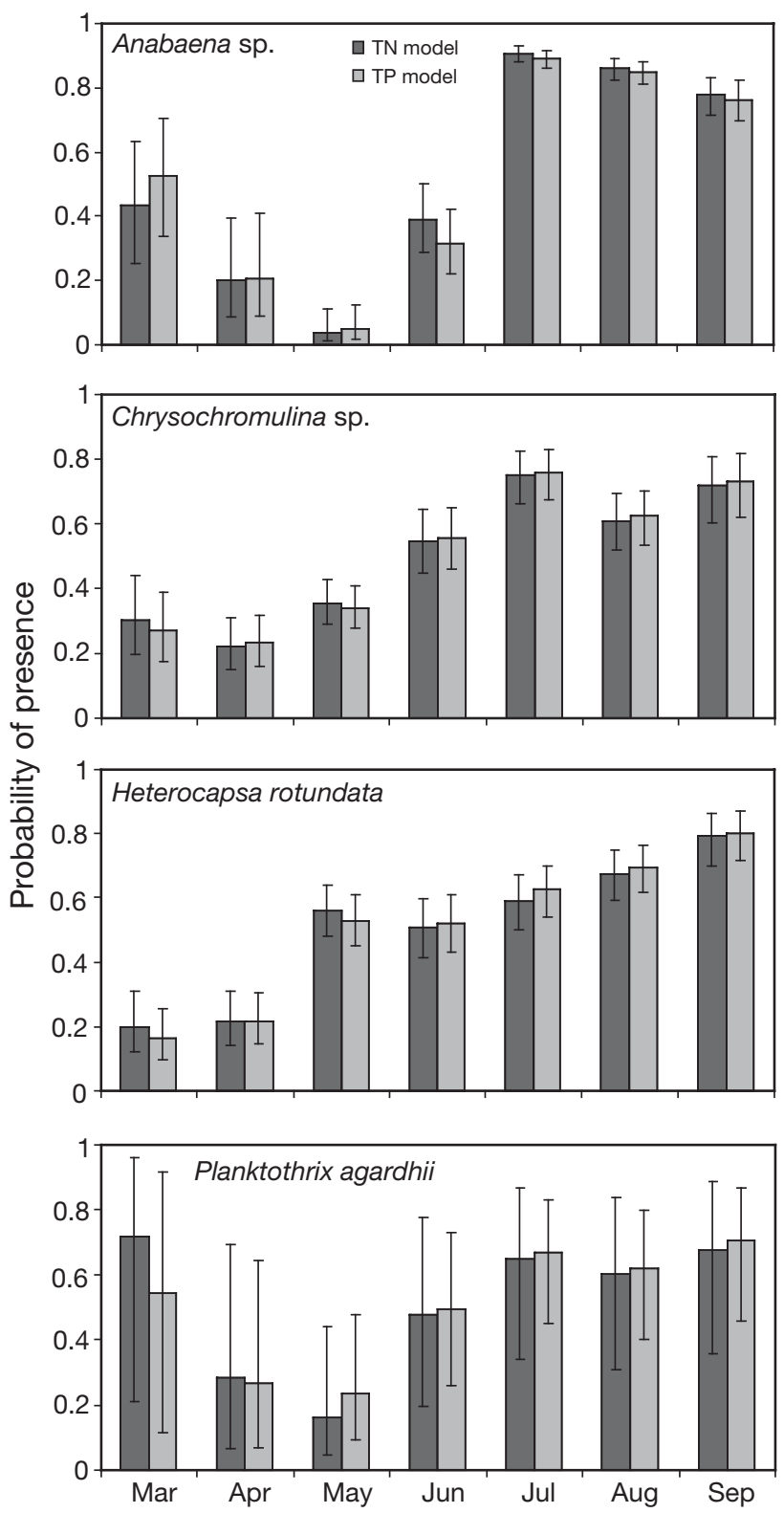

Fig. 8. Seasonal variations in probability of observing the 4 species most indicative of changes in TN and TP concentrations. Seasonal variation is scaled according to salinity and nutrient levels and adjusted to show an average presence of $50 \%$ for all months. Error bars show the 95\% confidence limits of the estimated probabilities

phosphorus limitation may not have been observed even if they were present.

Increasing nitrogen limitation should, in theory and as shown for lakes (e.g. Flett et al. 1980), favor the growth of cyanobacteria that are capable of fixing atmospheric nitrogen in addition to the dissolved inorganic sources. However, estuaries and coastal areas do not necessarily shift towards a phytoplankton community dominated by cyanobacteria when nitrogen be- 


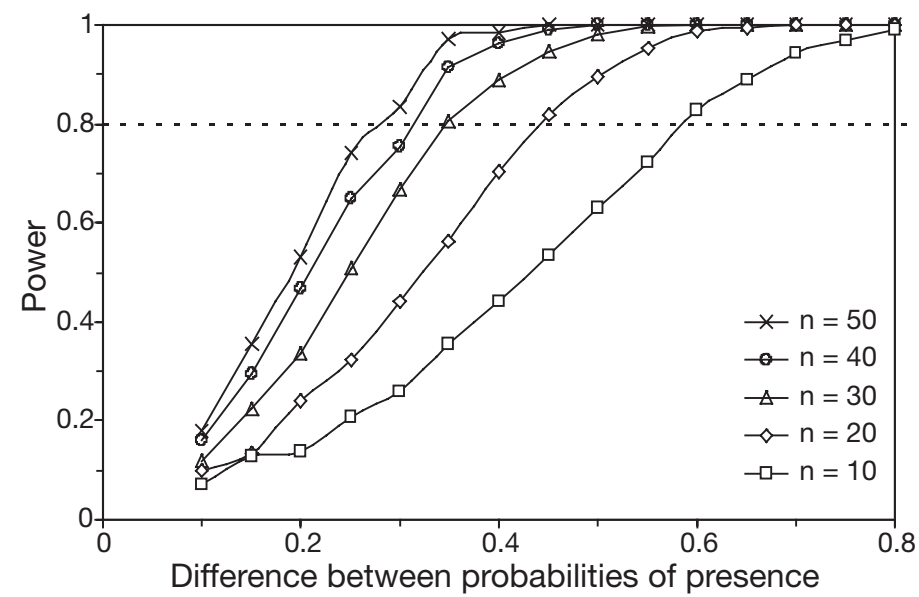

Fig. 9. Probability of detecting a difference in the probability of presence (i.e. statistical power) between 2 samples of size $n$ calculated as proportion of positive trials out of 1000 simulations

comes limiting (Howarth 1988). Stability of the water column affects cyanobacteria, and high light intensities have been shown to decrease the buoyancy by increasing the photosynthetate accumulation and resulting in increased turgor pressure and subsequent collapse of gas vacuoles (Grant \& Walsby 1977) regardless of the availability of nutrients or inorganic carbon (Spencer \& King 1989). In such cases, loss rates from sedimentation of cyanobacteria may exceed growth rates in the surface layer (Heiskanen \& Olli 1996). For cyanobacteria, 12 out of the 20 potential indicator species/genera responded significantly to TN levels, but the response surfaces were quite different in that 6 showed decreases in presence with increasing TN, 2 showed increases in presence with increasing $T N$, and 4 had optimum probability of presence at intermediate values of TN. On the other hand, most cyanobacteria species/genera (10 out of 14 significant responses) increased their probability of presence with $\mathrm{N}$ : $\mathrm{P}$ ratios increasing from low to intermediate values. This and the relatively high TN:TP ratios (Fig. 3) suggest that the ability to fix nitrogen may not be an important structuring mechanism for phytoplankton in this part of the Baltic Sea.

It can also be argued that it is the inorganic nutrients and not the TN and TP concentrations that are relevant to the structure of the phytoplankton community. Indeed, the bio-available fraction of TN and TP, including both inorganic and organic nutrients to be regenerated through the microbial loop, is most likely high in estuaries receiving discharges from cultivated fields and cities, and lower if discharges are from natural catchments. The high retention times of the Gulf of Riga and Gulf of Finland imply that the fraction of bioavailable $\mathrm{N}$ and $\mathrm{P}$ is even less for open waters. These trends in bio-available nutrients therefore generally follow the trends of TN and TP concentrations, suggesting that TN and TP levels and the amount of bioavailable nutrients are correlated.

In summary, our results show that the phytoplankton community is affected by changing nutrient levels but that these changes occur gradually and not abruptly. The strong stochastic elements associated with the selection of species representative of different nutrient levels, combined with the uncertainty in the analysis of the phytoplankton samples, lead to considerable variation in monitoring data.

\section{Application of method}

The outlined method of analysis is generic and can be applied to phytoplankton data from other regions to identify phytoplankton taxa or species that responds positively to elevated nutrient levels and thus can be considered as potential indicator species for eutrophication. Another application of the method presented is to combine the response surfaces with microfossil assemblages from paleoecological studies to estimate historical environmental conditions (e.g. Bianchi et al. 2000).

The method can also be applied to other phytoplankton indicators, for example on the higher taxonomical levels or on the life-form concept of Smayda \& Reynolds (2001). The screening tool allows the definition of taxonomic units or groups of phytoplankton that have a significant positive response to nutrient enrichment and for which biomass or abundance criteria for potential blooms can be defined. These indicators can then be applied in the further aggregation of phytoplankton (e.g. phytoplankton multimetric index) to allow more robust assessment and classification based on phytoplankton (e.g. Lacouture et al. 2006).

Acknowledgements. We gratefully thank the institutes responsible for the national marine monitoring programs in Estonia (Estonian Marine Institute), Finland (Finnish Environment Institute), Latvia (Institute of Aquatic Ecology) and the Alg@line project (Estonian Marine Institute and the Finnish Institute of Marine Research) for providing data to this study. This work is a contribution from the Research projects CHARM (EVK3-CT-2001-00065) and REBECCA (SSPI-CT2003-502158) supported by the European Union. The manuscript was greatly improved by valuable comments from 4 anonymous reviewers.

\section{LITERATURE CITED}

Anderson DM, Glibert PM, Burkholder JM (2002) Harmful algal blooms and eutrophication: nutrient sources, composition, and consequences. Estuaries 25:704-726

Berzinsh V (1995) Hydrology. In: Suursaar E (ed) Ecosystem 
of the Gulf of Riga between 1920 and 1990. Estonian Academy of Science A5, Estonian Academy Publishers, Tallinn, p 7-31

Bianchi TS, Engelhaupt E, Westman P, Andren T, Rolff C, Elmgren R (2000) Cyanobacterial blooms in the Baltic Sea: Natural or human-induced? Limnol Oceanogr 45:716-726

Carstensen J, Conley DJ, Andersen JH, Ærtebjerg G (2006) Coastal eutrophication and trend reversal: a Danish case study. Limnol Oceanogr 51:398-408

Cloern JE (2001) Our evolving conceptual model of the coastal eutrophication problem. Mar Ecol Prog Ser 210: 223-253

Conley DJ, Schelske CL, Stoermer EF (1993) Modification of the biogeochemical cycle of silica with eutrophication. Mar Ecol Prog Ser 101:179-192

Cottingham KL, Carpenter SR (1998) Population, community, and ecosystem variates as ecological indicators: Phytoplankton responses to whole-lake enrichment. Ecol Appl 8:508-530

Egge JK, Aksnes DL (1992) Silicate as regulating nutrient in phytoplankton competition. Mar Ecol Prog Ser 83:281-289

Escaravage V, Prins TC, Small AC, Peeters JCH (1996) The response of phytoplankton communities to phosphorus input reduction in mesocosm experiments. J Exp Mar Biol Ecol 198:55-79

Escaravage V, Prins TC, Nijdam C, Small AC, Peeters JCH (1999) Response of phytoplankton communities to nitrogen input reduction in mesocosm experiments. Mar Ecol Prog Ser 179:187-199

European Union (2000) Directive 2000/60/EC of the European Parliament and of the Council of 23 October 2000 establishing a framework for Community action in the field of water policy. Official Journal L 327/1

Flett RJ, Schindler DW, Hamilton RD, Campbell NER (1980) Nitrogen fixation in Canadian Precambrian shield lakes. Can J Fish Aquat Sci 37:494-505

Grant NG, Walsby AE (1977) The contribution of photosynthate to turgor pressure rise in the planktonic blue-green alga Anabaena flos-aquae. J Exp Bot 28:409-415

Gonzales EJ (2000) Nutrient enrichment and zooplankton effects on the phytoplankton community in microcosms from El Andino reservoir (Venezuela). Hydrobiologia 434: 81-96

Hallegraeff GM (1993) A review of harmful algal blooms and their apparent global increase. Phycologia 32:79-99

Heiskanen AS, Olli K (1996) Sedimentation and buoyancy of Aphanizomenon cf. flos-aquae (Nostocales, Cyanophyta) in a nutrient-replete and nutrient-depleted coastal area of the Baltic Sea. Phycologia 35:94-101

Heiskanen AS, van de Bund WJ, Cardoso AC, Nõges P (2004) Towards good ecological status of surface waters in Europe: interpretation and harmonisation of the concept. Water Sci Techol 49:169-177

HELCOM (2001) Manual for marine monitoring in the COMBINE programme of HELCOM, Part C. HELCOM, Helsinki. Available at: http://www.helcom.fi/groups/monas/CombineManual/PartC/en_GB/main/

HELCOM (2002) Environment of the Baltic Sea area 19941998. Balt Sea Env Proc 82B, Helsinki. Available at: http://www.helcom.fi/stc/files/Publications/Proceedings/ bsep82b.pdf

HELCOM (2004a) Checklist of Baltic Sea phytoplankton species. Balt Sea Env Proc 95, Helsinki. Available at: http://www.helcom.fi/stc/files/Publications/Proceedings/ bsep95.pdf

HELCOM (2004b) The 4th Baltic Sea pollution load compilation (PLC-4). Balt Sea Env Proc 93, Helsinki. Available at:
http://www.helcom.fi/stc/files/Publications/Proceedings/ bsep93.pdf

Helminen H, Juntura E, Koponen J, Laihonen P, Ylinen H (1998) Assessing of long distance background nutrient loading to the Archipelago Sea, northern Baltic with a hydrodynamic model. Environ Model Softw 13:511-518

Howarth RW (1988) Nutrient limitation of net primary production in marine ecosystems. Annu Rev Ecol Syst 19:89-110

Humborg C, Itekkot V, Cociasu A, von Bodungen B (1997) Effect of Danube River dam on Black Sea biogeochemistry and ecosystem structure. Nature 386:385-388

Humborg C, Conley DJ, Rahm L, Wulff F, Cociasu A, Itekkot $\mathrm{V}$ (2000) Silicon retention in river basins: far-reaching effects on biogeochemistry and aquatic food webs in coastal marine environments. Ambio 29:45-50

Johansson N, Granéli E (1999) Cell density, chemical composition and toxicity of Chrysochromulina popylepis in relation to different N:P supply ratios. Mar Biol 135:209-217

Johansson L, Wallström K (2001) Urban impact in the history of water quality in the Stockholm Archipelago. Ambio 30: $277-281$

Kauppila P, Hällfors G, Kangas P, Kokkonen P, Basova S (1995) Late summer phytoplankton species composition and biomasses in the eastern Gulf of Finland. Ophelia 42: 179-191

Klausmeier CA, Litchman E, Daufresne T, Levin SA (2004) Optimal nitrogen-to-phosphorus stoichiometry of phytoplankton. Nature 429:171-174

Kuosa H, Autio R, Kuuppo P, Setälä O, Tanskanen S (1997) Nitrogen, silicon and zooplankton controlling the Baltic spring bloom: an experimental study. Estuar Coast Shelf Sci 45:813-821

Lacouture RV, Johnson JM, Buchanan C, Marshall HG (2006) Phytoplankton index of biotic integrity for Chesapeake Bay and its tidal tributaries. Estuar Coast 29:598-616

Lancelot C (1995) The mucilage phenomenon in the continental coastal waters of the North-Sea. Sci Total Environ 165: 83-102

McCullagh P, Nelder JA (1989) Generalized linear models, 2nd edn. Chapman \& Hall/CRC, Boca Raton, FL

Niemi Å (1979) Blue-green algae blooms and N:P ratio in the Baltic Sea. Acta Bot Fenn 110:57-61

Oliver RL (1994) Floating and sinking in gas-vacuolate cyanobacteria. J Phycol 30:161-173

Olli K, Heiskanen AS, Seppälä J (1996) Development and fate of Eutreptiella gymnastica bloom in nutrient-enriched enclosures in the coastal Baltic Sea. J Plank Res 18:15871604

Olsen Y, Reinertsen H, Vadstein O, Andersen T and 11 others (2001) Comparative analysis of food webs based on flow networks: effects of nutrient supply on structure and function of coastal plankton communities. Cont Shelf Res 21: 2043-2053

Philippart CJM, Cadée GC, van Raaphorst W, Riegman R (2000) Long-term phytoplankton-nutrient interactions in a shallow coastal sea: algal community structure, nutrient budgets, and denitrification potential. Limnol Oceanogr 45:131-144

Pinckney JL, Paerl HW, Harrington MB (1999) Responses of the phytoplankton community growth rate to nutrient pulses in variable estuarine environments. J Phycol 35: $1455-1463$

Pires LMD, Bontes BM, Van Donk E, Ibelings BW (2005) Grazing on colonial and filamentous, toxic and non-toxic cyanobacteria by the zebra mussel Dreissena polymorpha. J Plankton Res 27:331-339

Pitkanen H, Tamminen T (1995) Nitrogen and phosphorus as 
production limiting factors in the estuarine waters of the eastern Gulf of Finland. Mar Ecol Prog Ser 129:283-294

Rabalais NN, Wiseman WJ, Turner RE, SenGupta BK, Dortch Q (1996) Nutrient changes in the Mississippi River and system responses on the adjacent continental shelf. Estuaries 19:386-407

Rhee GY, Gotham IJ (1980) Optimum N:P ratios and the coexistence of planktonic algae. J Phycol 16:486-489

Schindler DW (1987) Detecting ecosystem responses to anthropogenic stress. Can J Fish Aquat Sci 44(Suppl):6-25

Schollhorn E, Graneli E (1996) Influence of different nitrogen to silica ratios and artificial mixing on the structure of a summer phytoplankton community from the Swedish west coast (Gullmar fjord). J Sea Res 35:159-167

Seifert T, Kayser B (1995) A high resolution spherical grid topography of the Baltic Sea. Marine Science Reports 9, Institut für Ostseeforschung, Warnemünde, Germany, p 72-88

Sellner KG, Sellner SG, Lacouture RV, Magnien RE (2001) Excessive nutrients select for dinoflagellates in the stratified Patapsco River estuary: Margalef reigns. Mar Ecol Prog Ser 220:93-102

Smayda TJ (1997) Harmful algal blooms: their ecophysiology and general relevance to phytoplankton blooms in the sea. Limnol Oceanogr 42:1137-1153

Smayda TJ, Reynolds CS (2001) Community assembly in

Editorial responsibility: Otto Kinne (Editor-in-Chief), Oldendorf/Luhe, Germany marine phytoplankton: application of recent models to harmful dinoflagellate blooms. J Plankton Res 23:447-461

Spencer CN, King DL (1989) Role of light, carbon dioxide and nitrogen in regulation of buoyancy, growth and bloom formation of Anabaena flos-aquae. J Plankton Res 11:283296

Tilman D, Kilham SS, Kilham P (1982) Phytoplankton community ecology: the role of limiting nutrients. Annu Rev Ecol Syst 13:349-372

Tungaraza C, Rousseau V, Brion N, Lancelot C, Gichuki J, Baeyens W, Goevens L (2003) Contrasting nitrogen uptake by diatoms and Phaeocystis-dominated phytoplankton assemblages in the North Sea. J Exp Mar Biol Ecol 292:19-41

Utermöhl H (1958) Zur Vervollkommung der quantitativen Phytoplankton-Methodik. Mitt Int Ver Limnol 9:1-38

Yunev OA, Moncheva S, Carstensen J (2005) Long-term variability of vertical chlorophyll $a$ and nitrate profiles in the open Black Sea: eutrophication and climate change. Mar Ecol Prog Ser 294:95-107

Yurkovskis A (2004) Long-term land-based and internal forcing of the nutrient state of the Gulf of Riga (Baltic Sea). J Mar Syst 50:181-197

Yurkovskis A, Wulff F, Rahm L, Andruzaitis A, RodriguezMedina M (1993) A nutrient budget of the Gulf of Riga. Estuar Coast Shelf Sci 37:113-127

Submitted: November 21, 2005; Accepted: August 31, 2006 Proofs received from author(s): April 13, 2007 